\title{
Overcoming seed dormancy and rooting in air-layering polyembryonic seedlings of sapucaia (Lecythis pisonis Cambess.)
}

\author{
Caroline Palacio de Araujo* ${ }^{1}$, Rodrigo Sobreira Alexandre ${ }^{1}$, Thuanny Lins Monteiro Rosa ${ }^{1}$, Edilson Romais \\ Schmildt ${ }^{2}$, José Carlos Lopes ${ }^{3}$, José Eduardo Macedo Pezzopane ${ }^{1}$
}

\author{
${ }^{1}$ Federal University of Espírito Santo, Departamento de Ciências Florestais e da Madeira, Av. Governador \\ Lindemberg, CEP 29550-000, Jerônimo Monteiro, ES, Brazil \\ ${ }^{2}$ Federal University of Espírito Santo, Departamento de Ciências Agrárias e Biológicas, Rodovia BR-101 Norte, \\ Litorâneo, CEP 29932-540, São Mateus, ES, Brazil \\ ${ }^{3}$ Federal University of Espírito Santo, Departamento de Agronomia, Alto Universitário, Guararema, CEP 29500-000, \\ Alegre, ES, Brazil
}

\section{*Corresponding author: carolinepalacio@yahoo.com.br}

\section{Abstract}

Lecythis pisonis produces edible seeds rich in nutritional and functional elements such as selenium and are a great alternative to Brazilian nuts. The seeds have low germination, which may be related to physical dormancy imposed by tegument, meaning that polyembryonic seedlings can be a strategy to increase final stand. The objective of this work was to study methods to overcome seed dormancy and auxin induction in polyembryonic seedlings of pisonis. The experiment to break dormancy consisted of seven treatments: T1: intact seeds; T2: seeds scarified on hilum's opposite side; T3: seeds scarified hilum's adjacent region; T4: seeds scarified in lateral region; T5: seeds scarified in both opposite and adjacent region to the hilum; T6: T2 + immersion in water at 40 ${ }^{\circ} \mathrm{C} / 20$ minutes; T7: T2 + immersion in water at $60{ }^{\circ} \mathrm{C} / 5$ minutes. The experiment to induce rooting was arranged in a $2 \times 6$ factorial randomized complete block design (environments: A. greenhouse and B. greenhouse covered with black polyolefin (80\% shading) $x$ concentrations of indole-3-butyric acid (IBA): 0; 1000; 2000; 3000; 4000 and $5000 \mathrm{mg} \mathrm{L}^{-1}$ ), with four replicates of eight polyembryonic seedlings. Seed coat scarification in hilum's adjacent (T3) and lateral regions (T4) was the most efficient methods for breaking physical dormancy. IBA at $5000 \mathrm{mg} \mathrm{L}^{-1}$ promoted the greatest rhizogenesis of $L$. pisonis layers.

Keywords: Cultivation conditions; Indole-3-butyric acid; Sapucaia; Seed propagation; Seedling production.

Abbreviations: A- greenhouse; B-greenhouse covered with black polyolefin (80\% shading); ATE_average time of emergence; $E_{-}$ emergence; ESI_emergence speed index; IBA_indole-3-butyric acid; $\mathrm{KOH}_{\text {_ }}$ potassium hydroxide; $\mathrm{P} 2$ _ polyembryonic plants with two siblings; P3_polyembryonic plants with three siblings; P4_polyembryonic plants with four siblings; P6_polyembryonic plants with six siblings; $\mathrm{PY}$ _ dormancy as physical; $\mathrm{RH}_{\text {_ }}$ relative humidity; $\mathrm{T} 1$ - intact seeds; $\mathrm{T} 2$ _ seeds scarified on hilum's opposite side; T3_ seeds scarified hilum's adjacent region; T4_ seeds scarified in lateral region; T5_ seeds scarified in both opposite and adjacent region to the hilum; T6_T2 + immersion in water at $40{ }^{\circ} \mathrm{C} / 20$ minutes; T7_ T2 + immersion in water at $60{ }^{\circ} \mathrm{C} / 5$ minutes; TP_total number of polyembryonic plants.

\section{Introduction}

Lecythis pisonis Cambess. (Lecythidaceae), known as sapucaia, is a Brazilian native species, originated from Atlantic and Amazon Forests. It is an ornamental species, with large size, fissured trunks and produces large fruits containing edible and tasty almonds, rich in nutrients such as selenium (Lorenzi, 1998; Demoliner et al., 2018). It has a certain degree of polyembryony in its seeds, promoting existence of seedlings with two or more stems.

Rod excess that would normally be decapitated during seedlings transportation to the field can be used in vegetative propagation, aiming increase seedlings production, since seeds have difficult in germinating, emerging and generating uniform seedlings, very typical of forest species, such as Bertholletia excelsa HBK, which belongs to the same family (Lecythidaceae) (Silva et al.,
2009). On the other hand, clonal propagation is also difficult and can be hampered by chronological, physiological, and ontogenetic age of the parent plants what makes vegetative propagation techniques more efficient in juvenile tissues to facilitate rooting.

Root induction in branches of tree species through layering, in comparison with cuttings, has the main advantage that propagated portion continues to receive water and photoassimilates from parent plant, increasing propagule survival. However, parent plant must be in good nutritional condition and in favorable sites (Vacek et al., 2012).

Rooting environment may also influence plant photosynthesis and consequently production and translocation rates of photoassimilates, which are fundamental to the energy supply necessary for rooting. This 
was observed in leafy cuttings of Corylus avellana L. in which light was essential to increase carbohydrate production and favor root formation, confirming that rooting is a costly process and requires a good amount of carbon skeletons (Tombesi et al., 2015).

This work aimed to study methods of breaking seed dormancy and auxin root induction in juvenile layers of polyembryonic L. pisonis.

\section{Results}

\section{Overcoming integumentary dormancy in L. pisonis seeds}

Intact seeds had the lowest seedling emergence percentage (18\%). Seeds scarified in adjacent and lateral region to the hilum showed the highest emergence percentages, highest emergence speeds and shortest mean emergence times (approximately 53 days), with no significant difference, but superior to intact seeds. Seeds scarified on the hilum's opposite side had low seedling emergence (36\%). Immersion in water at 40 and $60^{\circ} \mathrm{C}$ of seeds scarified on the opposite side of the hilum gave low percentages, low speeds, and higher mean emergence times of seedlings (Table 1).

\section{Root induction using auxin in air-layering of polyembryonic pisonis}

Polyembryony was observed among total L. pisonis seedlings. Average number of polyembryonic seedlings in the four plots was $39 \%$, varying from $19.86 \%$ (plot A); $29.82 \%$ (plot B); $40.08 \%$ (plot C); to $66.80 \%$ (plot D), indicating that this characteristic may be related to parent plant, that is, to the genetic factor. The highest percentage of siblings per seed were two, forming seedlings with two shoots (mean of $32.3 \%$ ), followed by seedlings with three shoots (mean of $11.5 \%$ ), while the lowest percentages were for seedlings with four (mean of $1.2 \%$ ) and six shoots (mean of $0.1 \%)$.

During rooting of polyembryonic seedlings layers, no significant difference was found between the two tested environments for callusing (\%), rooting (\%), and length of the largest root $(\mathrm{cm})$ variables, with mean values of $(A: 89.58$; $B$ : 92.19), (A: 11.98; B: 9.90), and (A: 4.42: B: 4.16), respectively. However, seedlings that remained in greenhouse ( $80 \%$ shading) (environment B) reached $8 \%$ more layers survival, but with fewer roots (Table 2 ).

Rooting percentage $(26.56 \%)$ showed a quadratic increase while root number (7.64) and length of the largest root (6.85 $\mathrm{cm}$ ) had linear increases, reaching the highest values in 5000 $\mathrm{mg} \mathrm{L}^{-1}$ of IBA concentration (Figs $2 \mathrm{~A}, \mathrm{~B}$, and $\mathrm{C}$, respectively). No influence of IBA concentrations was found on survival (Fig 3A) and callusing (Fig 3B) of layers in both environments. Air-layering of $L$. pisonis polyembryonic seedlings (Fig 4A) (Fig 4B, detail in C) without auxin in greenhouse resulted in lower callusing in ring region (Fig $4 \mathrm{D}$ ) and formation of fine and lateral roots (Fig $4 \mathrm{~J}$ ). Shoots treated with auxin formed larger areas of calli (Fig 4E-G) and, in higher concentrations, a pronounced indirect dedifferentiation of calli into roots (Fig $4 \mathrm{H}$ and I) with thicker roots formation (4K-O).

Seedlings ring region kept in greenhouse (80\% shading) (Fig $4 \mathrm{P}-\mathrm{U}$ ) showed a larger tissue protuberance than seedlings in the greenhouse (Fig 4D-I), resulting in a lower number of roots (2.63) (Fig 3) but larger ones.

Tegument physical scarification in the adjacent and lateral region to hilum contributed significantly to the emergence and vigor of seedlings. The concentration of $5000 \mathrm{mg} \mathrm{L}^{-1}$ promoted the highest percentage of rooting in sapucaia juvenile stem.

\section{Discussion}

Constitution of seed coat contributes to characterize vigor and germinative capacity of seeds under natural conditions. Seeds with hard and thick tegument usually present physical numbness, which can be broken through removal or damage through mechanical scarification, chemical cracking and external coating. These damages break the barrier that hinders water entry and gas exchanges, allowing germination processes to start (Arruda et al., 2015).

In the present work, we verified that intact seeds of $L$. pisonis have low seedling emergence (Table 1), suggesting some type of dormancy. We confirmed this dormancy as physical (PY), considering that scarification of seed coat in adjacent and lateral region to hilum, entry site of water into seed, showed increased percentage and speed of emergence of seedlings (Table 1). In these cases, tegument partial removal facilitated absorption of water by seed and advanced protrusion of primary root. However, root and epicotyl emerged in $41 \%$ of seeds without seed coat of $B$. excelsa (Lecythidaceae), characterizing endogenous dormancy (Silva et al., 2009). Thus, we also need to investigate whether $L$. pisonis seeds present some type of inhibition to germination.

Scarification on the opposite side of hilum resulted in low seedling emergence (Table 1), which may have delayed water to reach embryo and trigger metabolic processes of germination, what explains in part biotic interventions of bacteria and fungi in the starch-rich endosperm, evolving to seed deterioration.

In B. excelsa seeds, hilum as well wrinkled and uneven seed coat surface provided by its cell wall porosity are the structures responsible for the entry of microorganisms and moisture absorption, contributing to proliferation of fungi of the genus Aspergillus. Fungal proliferation allows insect attacks, while insects can disseminate fungi and contribute to nut deterioration (Scussel et al., 2014).

Each plant species has its optimum temperature for activate germination processes, in which soil will have the ideal temperature that will provide maximum germination in a shorter period of time. When temperature exceeds optimal limit, it will cause seed death due to embryo desiccation and denaturation of proteins and other membrane compounds (Ribeiro and Borghetti, 2014).

In the present work, exposure of scarified seeds to temperatures of 40 and $60{ }^{\circ} \mathrm{C}$ (Table 1) seems to have induced thermoinhibition or thermodormancy. Seed response to high temperature stress is related to the maternal genotype under nuclear control of the embryo (Rix et al., 2012). High temperature-induced stress reduces germination because of a differential threshold to induce dormancy or cause embryo mortality (Rix et al., 2015). However, this author points out that genetic differences in germination response, including rapid germination and seedling growth in high temperature environments, are related to adaptive processes.

L. pisonis seeds scarification, which allowed endosperm exposure to temperatures of $40{ }^{\circ} \mathrm{C}$ and $60{ }^{\circ} \mathrm{C}$, may have increased enzyme activity (superoxide dismutase (SOD) and catalase (CAT)) and hydrogen peroxide $\left(\mathrm{H}_{2} \mathrm{O}_{2}\right)$ for the metabolism of reactive oxygen species, membrane damage 
Table 1. Emergence of L. pisonis seedlings as a function of physical seed coat scarification and heat treatments.

\begin{tabular}{|c|c|c|c|}
\hline Treatments & $\mathrm{E}(\%)$ & ESI & ATE (days) \\
\hline T1. Intact seeds & $18.0 b^{(1)}$ & $0.0630 \mathrm{~b}$ & $57.00 \mathrm{~b}$ \\
\hline T2. Seeds scarified on hilum's opposite side & $36.0 \mathrm{~b}$ & $0.1379 b$ & $70.00 \mathrm{a}$ \\
\hline T3. Seeds scarified in hilum's adjacent region & $74.0 \mathrm{a}$ & 0.3618 a & $53.00 \mathrm{~b}$ \\
\hline T4. Seeds scarified in lateral region & $68.0 \mathrm{a}$ & $0.3341 \mathrm{a}$ & $53.75 \mathrm{~b}$ \\
\hline T5. Seeds scarified in hilum's opposite and adjacent regions & $28.0 \mathrm{~b}$ & $0.1015 b$ & $74.25 \mathrm{a}$ \\
\hline T6. $\mathrm{T} 2+$ immersion in water at $40^{\circ} \mathrm{C} / 20$ minutes & $22.0 \mathrm{~b}$ & $0.0761 \mathrm{~b}$ & $75.75 \mathrm{a}$ \\
\hline T7. $\mathrm{T} 2+$ immersion in water at $60^{\circ} \mathrm{C} / 5$ minutes & $22.5 \mathrm{~b}$ & $0.0692 \mathrm{~b}$ & $82.25 \mathrm{a}$ \\
\hline
\end{tabular}

${ }^{(1)}$ Means followed by the same letter within column are not significantly different by Tukey test $(\mathrm{p}<0.05)$. E = Emergence; ESI = Emergence speed index; ATE = Average time of emergence.

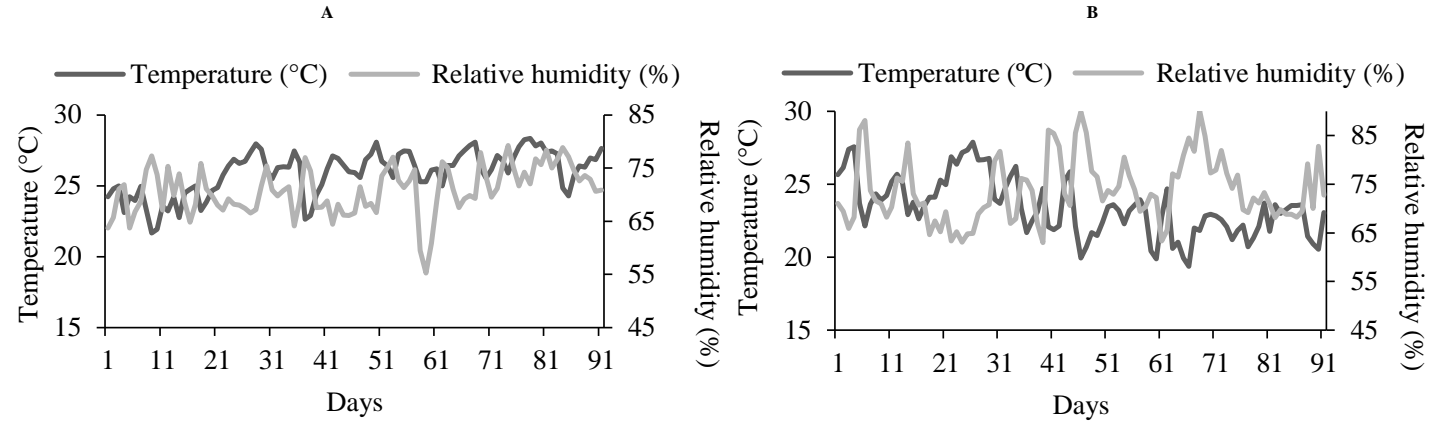

Fig 1. Daily means of temperature and relative humidity in greenhouse (A) and greenhouse (80\% shading) (B) during 91 days of layering polyembryonic $L$. pisonis seedlings.

Table 2. Percentage of callusing, rooting and survival, number and length of roots $L$. pisonis layers maintained in different environments.

\begin{tabular}{lcc}
\hline & \multicolumn{2}{c}{ Environments } \\
\cline { 2 - 3 } Characteristics & $\mathrm{A}$ & $\mathrm{B}$ \\
\hline Callusing (\%) & $89.58 \mathrm{a}^{(1)}$ & $92.19 \mathrm{a}$ \\
Rooting (\%) & $11.98 \mathrm{a}$ & $9.90 \mathrm{a}$ \\
Survival (\%) & $90.63 \mathrm{~b}$ & $98.96 \mathrm{a}$ \\
Number of roots & $5.01 \mathrm{a}$ & $2.63 \mathrm{~b}$ \\
Length of the largest root $(\mathrm{cm})$ & $4.42 \mathrm{a}$ & $4.16 \mathrm{a}$ \\
\hline \multicolumn{1}{l}{ Means followed by the same letter within row, are not significant different by Tukey test $(p<0.05)$. A = greenhouse; $\mathrm{B}=$ greenhouse covered with black polyolefin (80\% shading). }
\end{tabular}
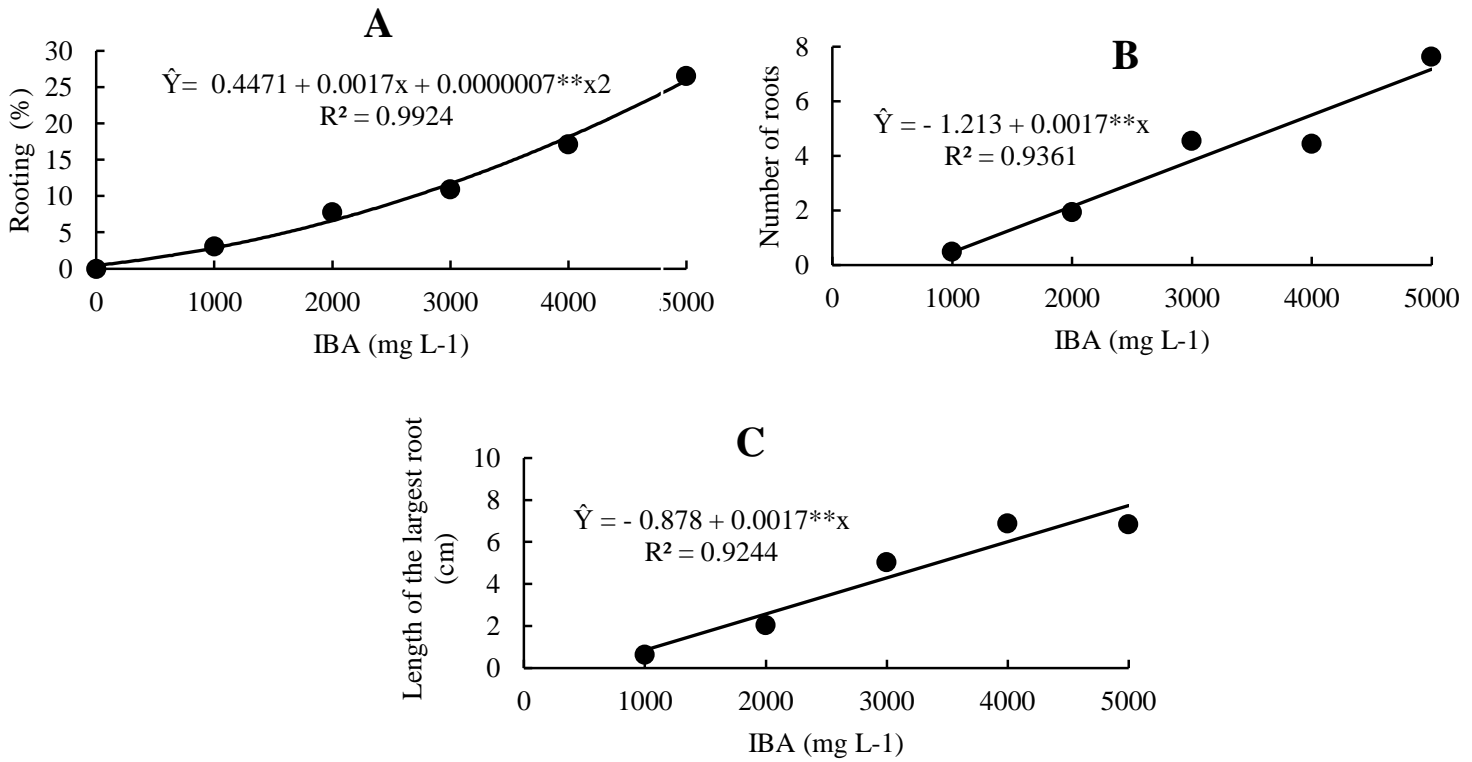

Fig 2. Rooting (\%) (A), number (B) and length (C) of roots of L. pisonis layers treated with different concentrations of IBA. ${ }^{* *}$ Significant at $1 \%$ probability. 

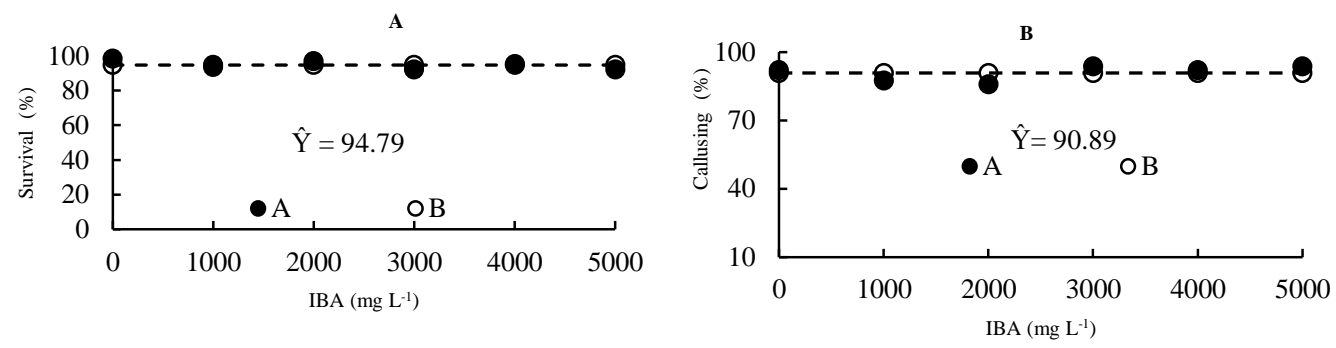

Fig 3. Callusing and survival (\%) of sapucaia (L. pisonis) layers treated with different concentrations of IBA in two different environments. $A$ = greenhouse; $B=$ greenhouse covered with black polyolefin ( $80 \%$ shading).

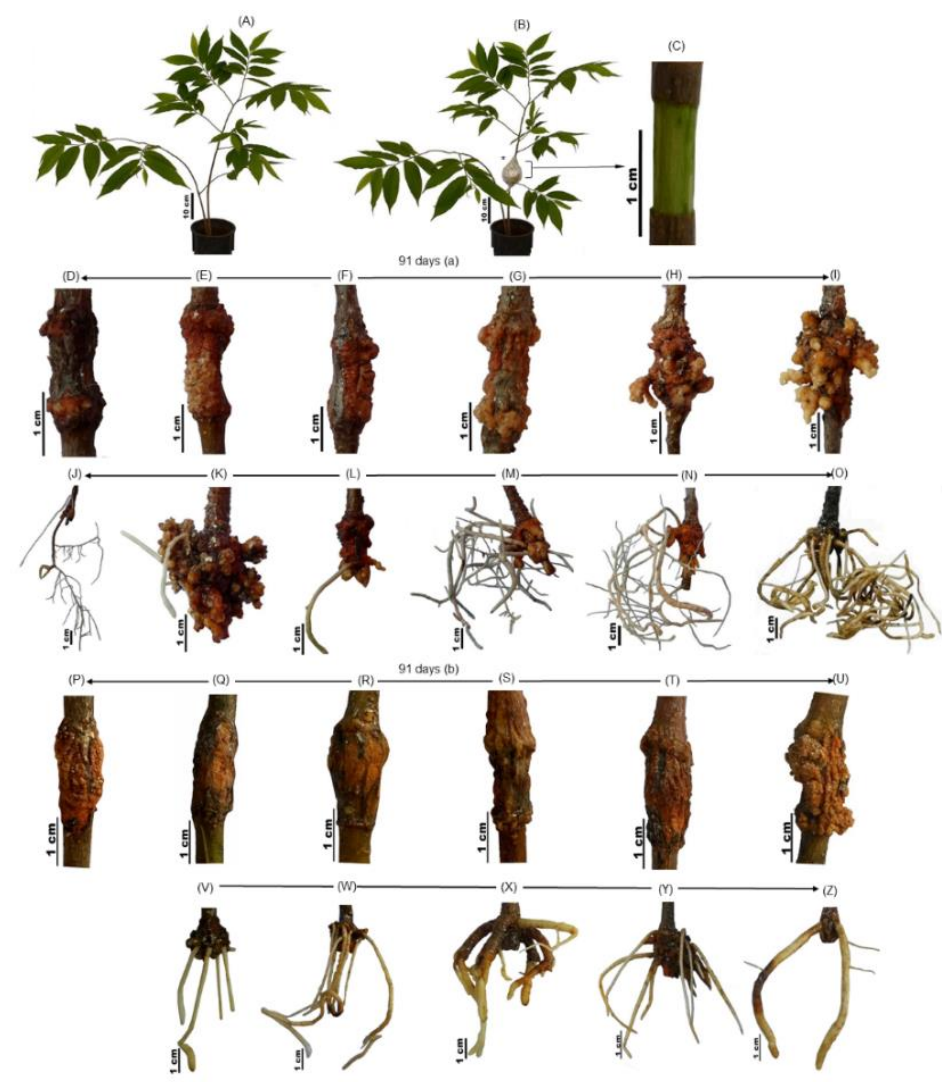

Fig 4. Rooting of polyembryonic L. pisonis layers with auxin induction after 91 days. (A) Polyembryonic seedling with two shoots. (B) Layering one of the polyembryonic seedling (asterisk) shoots . (C) Detail of the wound in one of the polyembryonic seedling shoots; D-Z. Details of the wounded region after 91 days in greenhouse and greenhouse covered with black polyolefin (80\% shading) $x$ concentrations of IBA, showing callusing and rooting. a) Greenhouse: D and J. $0 \mathrm{mg} \mathrm{L}^{-1} ; \mathrm{E}$ and K. $1000 \mathrm{mg} \mathrm{L}^{-1} ; \mathrm{F}^{\text {and L. }} 2000 \mathrm{mg} \mathrm{L}^{-1} ; \mathrm{G}$ and M. $3000 \mathrm{mg} \mathrm{L}^{-1} ; \mathrm{H}$ and N. $4000 \mathrm{mg} \mathrm{L}^{-1} ;$ I and O. $5000 \mathrm{mg} \mathrm{L}^{-1}$ of IBA. b) $80 \%$ shading: P. $0 \mathrm{mg} \mathrm{L}^{-1} ; \mathrm{Q}$ and V. $1000 \mathrm{mg} \mathrm{L}^{-1} ; \mathrm{R}^{-1}$ and W. $2000 \mathrm{mg} \mathrm{L}^{-1} ; \mathrm{S}$ and X. $3000 \mathrm{mg} \mathrm{L}^{-1} ; \mathrm{T}$ and Y. $4000 \mathrm{mg} \mathrm{L}^{-1} ; \mathrm{U}$ and Z. $5000 \mathrm{mg} \mathrm{L}^{-1}$ IBA. "This figure is colorful in the electronic version".

such as lipid peroxidation, and electrolyte leakage (Barreto and Garcia, 2017).

Lecythis pisonis has some degree of polyembryony in its seeds, giving rise to seedlings with two or more siblings. This work aimed to double the number of seedlings in final stand by rooting through air layering one of the juvenile shoots of the polyembryonic seedlings, considering that $L$. pisonis seeds without any pre-germination treatment have low germination (18\%) and, even with scarification, reach losses of $26 \%$ in germination as observed in intact seeds (Table 1 ). Polyembryony is the phenomenon of occurrence of two or more embryos in a seed, most often caused by gametophytic or sporophytic apomixia (Batygina and Vinogradova, 2007).
IBA had a positive effect on rooting of polyembryonic $L$. pisonis seedlings, showing increasing quadratic behavior, but with low adventitious rooting percentage (Fig 2B) and increasing linear root growth (Fig $2 \mathrm{C}$ ), with both variables showing better responses with increase in auxins concentrations. Low rooting may result from different factors, including genetic, hormonal composition, and degree of tissues lignification. In studies with cuttings of Tectona grandis L. aged two months, 15, and 30 years showed that auxins influenced the increase in soluble sugar, starch, and peroxidase activity while these factors decreased with plant aging, contributing to gradual rooting reduction (Husen and Pal, 2007). 
Other species are also difficult to root, for example, middle and basal juvenile cuttings of $B$. excelsa treated with IBA (1000 $\mathrm{mg} \mathrm{L}^{-1}$ ) showed higher rooting percentages, 58.3\% and $41.7 \% \%$, respectively. However, cuttings formed one root on average. The longest root lengths were recorded in middle cuttings treated with $3000 \mathrm{mg} \mathrm{L}^{-1}$ IBA $(7.0 \mathrm{~cm})$ and $1000 \mathrm{mg} \mathrm{L}^{-1}$ IBA $(6.4 \mathrm{~cm})$ (Cordeiro et al., 2016). These findings confirm, therefore, the difficulty of $L$. pisonis and $B$. excelsa to root.

Formation of adventitious roots is usually preceded by callus formation, which is the tissue involved in healing process. In this study, layers of $L$. pisonis achieved a high percentage of callusing in both tested environments (A. 89.58 and B. $92.19 \%$ ) (Table 3). Fig 3B shows that callus formation was not influenced by IBA concentrations.

Strong callus formation may have acted as a negative factor in root formation as found in studies with five tropical species, Anogeissus latifolia (Roxb. Ex DC.) Wallich ex Bedome, Boswellia serrata Roxb., Dalbergia latifolia, Gmelina arborea Roxb., and Dalbergia sisso Roxb., where the increase in rooting was inversely proportional to callus formation. D. sisso treated with IBA $\left(100 \mathrm{mg} \mathrm{L}^{-1}\right)$ and $B$. serrata with IBA $\left(100 \mathrm{mg} \mathrm{L}^{-1}\right)+$ Thiamine- $\mathrm{HCl}\left(100 \mathrm{mg} \mathrm{L}^{-1}\right)$ formed no callus and reached 83 and $100 \%$ of rooting, respectively, while the others had higher callus production and lower root formation (Singh and Ansari, 2014).

There is a strong relationship between absence of auxin and low callusing (Fig 4D and P), formation of thin and lateral roots (Fig 4J), and higher callusing (Fig $4 \mathrm{I}$ and $\mathrm{U}$ ) and formation of thicker roots (Fig $4 \mathrm{~K}-\mathrm{O}$ and $\mathrm{V}$-Z) at higher auxin concentrations. Suitable balance of auxin/cytokine ratio may have been compromised, suggesting the supply of either cytokinins or the combination of cytokinins with auxins for future work.

Adventitious roots formation from caulinar tissue is a complex process, since cells destined for stem formation will have to lose their specific characteristics, and acquire new meristematic activities. For this to occur, an endogenous hormonal balance is required through a high auxin/cytokine ratio.

In the present study, the highest auxin concentration (5000 $\mathrm{mg} \mathrm{L}^{-1}$ ) resulted in the highest number of roots per shoot (7.64) (Fig 2B). Number of roots and their anatomical characteristics influenced survival of vegetatively propagated individuals in the field. Adventitious rooting may originate from phloem or vascular cambium and their origin is not restricted to one particular position, what allows treatments aiming production of a greater number of roots per cutting (Bryant and Trueman, 2015).

Materials and Methods

\section{Germination}

Fruits were harvested from two matrices located in Laranja de Terra, Espírito Santo, aged 30 and 50 years. Then they dried under shaded condition until operculum opening (lid) with released seeds sown in organic substrate. Seeds were subjected to six treatments of physical scarification and immersion in hot water. Physical scarification of seed coat was carried out using an Invicta LI-15 belt sander, with a 50 grit yellow abrasive belt.

Experiment was arranged in a completely randomized design, with four replicates of 25 seeds, and seven treatments: T1: intact seeds; T2: seeds scarified on hilum's opposite side; T3: seeds scarified in hilum's adjacent region; T4: seeds scarified in lateral region; T5: seeds scarified in hilum's opposite and adjacent regions; T6: $\mathrm{T} 2+$ immersion in water at $40{ }^{\circ} \mathrm{C} / 20$ minutes; T7: T2 + immersion in water at $60{ }^{\circ} \mathrm{C} / 5$ minutes. Forty days after sowing, plantules emergence (Brasil, 2009), plantules speed emergence index (ESI) (Maguire, 1962), and average time of emergence (ATE) (Labouriau, 1983) were daily evaluated after emergence of $L$. pisonis seedlings on Bioplant substrate within tubes of 288 $\mathrm{cm}^{3}$. Data were submitted to analysis of variance, and means were compared by Tukey test, at $5 \%$ probability level (Cruz, 2016).

\section{Auxin root induction in layers of polyembryonic seedlings of L. pisonis within two environments}

First, polyembryony percentage was calculated in $1000 \mathrm{~L}$. pisonis seedlings distributed in four lots. Polyembryonic plants with two siblings (P2); three siblings (P3); four siblings (P4); six siblings (P6), and total number of polyembryonic plants (TP) were counted in each lot. Then polyembryonic seedlings were transplanted into $3780 \mathrm{~cm}^{3}$ tubes, beginning the layering experiment with one of the shoots after 20 months, using indole-3-butyric acid (IBA) at concentrations of $0 ; 1000 ; 2000 ; 3000 ; 4000$ and $5000 \mathrm{mg} \mathrm{L}^{-1}$. Auxin concentrations were diluted in $500 \mu \mathrm{L}$ of $1 \mathrm{~N}$ potassium hydroxide $(\mathrm{KOH})$, adding liquid lanolin until reach $10 \mathrm{~mL}$.

A $1.5 \mathrm{~cm}$ wide ring of bark was cut on the middle of a shoot of each polyembryonic seedling and removed. IBA was applied on the wood with a brush. Cut was covered with a thin plastic bag opened at both ends. Lower end was tied with string and the bag filled with moistened vermiculite substrate, while upper end was tied with string. Plastic bag was wrapped with aluminum foil to avoid photodegradation of auxin.

After experiment set up, each layer was moistened with 20 $\mathrm{mL}$ of water using a syringe. No other watering were needed during experimental period (91 days). Polyembryonic seedlings with their respective layers were separated into two environments with temperature $\left({ }^{\circ} \mathrm{C}\right)$ and relative humidity (\%) being daily measured. Characteristics evaluated were: survival (\%), callusing (\%), rooting (\%), number of roots and length of the largest root $(\mathrm{cm})$.

Environmental condition during 91 days of experiment reached in environment $A$, temperature and humidity with maximum values $\left(30.68{ }^{\circ} \mathrm{C}\right.$ and $\left.83.07 \%\right)$ and minimum values $\left(21.75{ }^{\circ} \mathrm{C}\right.$ and $\left.50.53 \%\right)$ respectively (Fig 1A). While environment B $(80 \%$ black mesh shading) achieved maximums $\left(24.09{ }^{\circ} \mathrm{C}\right.$ and $\left.76.79 \%\right)$ and minimums $\left(22.73{ }^{\circ} \mathrm{C}\right.$ and $70.79 \%$ ) (Fig 1B).

Experiment was arranged in a $2 \times 6$ factorial randomized complete block design (environment: $A$. greenhouse and B. greenhouse covered with black polyolefin ( $80 \%$ shading) $x$ concentrations of indole-3-butyric acid (IBA): 0; 1000; 2000; 3000; 4000 and $5000 \mathrm{mg} \mathrm{L}^{-1}$ ), with four replicates of eight polyembryonic seedlings. Data were examined by analysis of variance and regression of the means regarding different IBA concentrations at $5 \%$ significance (Cruz, 2016).

\section{Conclusions}

Physical scarification of seed coat in the region adjacent to hilum and in its lateral region of $L$. pisonis seeds were the most efficient methods for overcoming dormancy. IBA promoted rooting of polyembryonic $L$. pisonis seedlings with 
increasing quadratic behavior, showing the best result in $5000 \mathrm{mg} \mathrm{L}^{-1}$ concentration. Further investigation with higher IBA concentrations is recommended to determine optimal conditions for $L$. pisonis rooting.

\section{Acknowledgements}

Authors thank the CNPq № 12/2016 - process 309406/20161 and Foundation for Support of Research and Innovation of Espírito Santo for granting scholarship to research organizer Prof. Dr. Rodrigo Sobreira Alexandre; the Federal University of Espírito Santo for providing facilities and equipment required during research; to Dario Antonio Fioresi Moreira, Janete Valani, Roberto da Costa, and Fernando de Paula for kindly supplying the seeds used in this work.

\section{References}

Arruda DM, Brandão DO, Veloso MDM, Nunes YRF (2015) Seed germination of three species of Fabaceae typical of seasonally dry forest. Pesq Flor Bras. 35: 135-142.

Barreto LG, Garcia QS (2017) Accelerated ageing and subsequent imbibition affect seed viability and the efficiency of antioxidant system in macaw palm seeds. Acta Physiol Plant. 39: 186- 194.

Batygina TB, Vinogradova GY (2007) Phenomenon of polyembryony. Genetic heterogeneity of seeds. Russ J Dev Biol. 38: 126-151.

Brasil. Ministério da Agricultura, Pecuária e Abastecimento (2009) Regras para análise de sementes. MAPA/DAS/ACS. 395p.

Bryant PH, Trueman SJ (2015) Stem anatomy and adventitious root formation in cuttings of Angophora, Corymbia and Eucalyptus. Forests. 6: 1227-1238.

Cordeiro IMCC, Lameira OL, Oliveira FA, Wendling I (2016) Rooting of juvenile cuttings of Bertholletia excelsa under diferente concentrations of indolebutyric acid. Agrociencia 50: 227-238.

Cruz CD (2016) Genes Software - extended and integrated with the R, Matlab and Selegen. Acta Sci. Agron. 38: 547552.

Demoliner F, Policarpi PB, Vasconcelos LFL, Vitali L, Micke GA, Block JM (2018) Sapucaia nut (Lecythis pisonis Cambess) and its by-products: A promising and underutilized source of bioactive compounds. Part I: Nutritional composition and lipid profile. Food Res Int. 112: 434- 442.
Husen A, Pal M (2007) Metabolic changes during adventitious root primordium development in Tectona grandis Linn. f. (teak) cuttings as affected by age of donor plants and auxin (IBA and NAA) treatment. New Forest. 33: 309-323.

Labouriau LG (1983) A germinação das sementes. Washington: OEA. $174 \mathrm{p}$.

Lorenzi H (1998) Árvores brasileiras: Manual de identificação e cultivo de plantas arbóreas nativas do Brasil. 2a ed. Nova Odessa: Plantarum. 352p.

Maguire JD (1962) Speed of germination: aid in selection and evaluation for seedling emergence and vigor. Crop Sci. 2: 176-177.

Ribeiro LC, Borghetti F (2014) Comparative effects of desiccation, heat shock and high temperatures on seed germination of savanna and forest tree species. Austral Ecol. 39: 267-278.

Rix KD, Gracie AJ, Potts BM, Brown PH, Gore PL (2015) Genetic control of Eucalyptus globulus seed germination. Ann For Sci. 72: 457-467.

Rix KD, Gracie AJ, Potts BM, Brown PH, SPURR CJ, GORE PL (2012) Paternal and maternal effects on the response of seed germination to high temperatures in Eucalyptus globulus. Ann For Sci. 69: 673-679.

Scussel VM, Manfio D, Savi GD, Moecke EHS (2014) Stereo and scanning electron microscopy of in shell Brazil nut (Bertholletia excelsa H.B.K.): part two surfasse sound nut fung spoilage susceptibility. J Food Sci. 79: 2392-2403.

Silva AN, Coelho MFB, Guimarães SC, Albuquerque MCF (2009) Germinação de sementes de castanheira-do-pará armazenadas em areia úmida. Pesq Agropec Bras. 44: 1431-1436.

Singh S, Ansari SA (2014) Callus formation impedes adventitious rhizogenesis in air layers of broadleaved tree species. Ann. For. Res. 57: 47-54.

Tombesi S, Palliotti A, Poni S, Farinelli D (2015) Influence of light and shoot development stage on leaf photosynthesis and carbohydrate status during the adventitious root formation in cuttings of Corylus avellana L. Front Plant Sci. 6: 1-13.

Vacek S, Hejcmanová P, Hejcman M (2012) Vegetative reproduction of Picea abies by artificial layering at the ecotone of the alpine timberline in the Giant (Krkonoše) Mountains, Czech Republic. Forest Ecol Manag. 263: 199207. 